\title{
Tropospheric ozone climatology at two Southern Hemisphere tropical/subtropical sites, (Reunion Island and Irene, South Africa) from ozonesondes, LIDAR, and in situ aircraft measurements
}

\author{
G. Clain ${ }^{1}$, J. L. Baray ${ }^{1,2}$, R. Delmas ${ }^{1}$, R. Diab ${ }^{3}$, J. Leclair de Bellevue ${ }^{4}$, P. Keckhut ${ }^{4,5}$, F. Posny ${ }^{1}$, J. M. Metzger ${ }^{1}$, and \\ J. P. Cammas ${ }^{6}$ \\ ${ }^{1}$ Laboratoire de L'Atmosphère et des Cyclones (LACy), UMR-CNRS 8105, 15, av. René Cassin, BP 7151, \\ 97715 St-Denis Cedex 9, La Réunion, France \\ ${ }^{2}$ Institut Pierre-Simon Laplace (IPSL), Univ. Versailles Saint Quentin, 5 Boulevard d'Alembert, 78280 Guyancourt, France \\ ${ }^{3}$ School of environmental science, University of KwaZulu-Natal, Durban, South Africa \\ ${ }^{4}$ Service d'Aéronomie (SA), UMR-CNRS 7620 Univ. Pierre et Marie Curie, 4 place Jussieu, 75252 Paris Cedex 05, France \\ ${ }^{5}$ Service d'Aéronomie (SA), UMR-CNRS 7620 Verrières le Buisson, 91371, France \\ ${ }^{6}$ Laboratoire d'Aérologie (LA), UMR-CNRS 5560 14, av. Edouard Belin, 31400 Toulouse, France
}

Received: 12 March 2008 - Published in Atmos. Chem. Phys. Discuss.: 9 June 2008

Revised: 23 January 2009 - Accepted: 23 January 2009 - Published: 6 March 2009

\begin{abstract}
This paper presents a climatology and trends of tropospheric ozone in the Southwestern Indian Ocean (Reunion Island) and South Africa (Irene and Johannesburg). This study is based on a multi-instrumental dataset: PTU-O ozonesondes, DIAL LIDAR and MOZAIC airborne instrumentation.

The seasonal profiles of tropospheric ozone at Reunion Island have been calculated from two different data sets: ozonesondes and LIDAR. The two climatological profiles are similar, except in austral summer when the LIDAR profiles show greater values in the free troposphere, and in the upper troposphere when the LIDAR profiles show lower values during all seasons. These results show that the climatological value of LIDAR profiles must be discussed with care since LIDAR measurements can be performed only under clear sky conditions, and the upper limit of the profile depends on the signal strength.

In addition, linear trends have been calculated from ozonesonde data at Reunion and Irene. Considering the whole tropospheric column, the trend is slightly positive for Reunion, and more clearly positive for Irene. Trend calculations have also been made separating the troposphere into
\end{abstract}

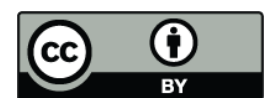

Correspondence to: G. Clain (gaelle.clain@univ-reunion.fr) three layers, and separating the dataset into seasons. Results show that the positive trend for Irene is governed by the lower layer that is affected by industrial pollution and biomass burning. On the contrary, for Reunion Island, the strongest trends are observed in the upper troposphere, and in winter when stratosphere-troposphere exchange is more frequently expected.

\section{Introduction}

Ozone is a major greenhouse gas (Lacis et al., 1990), and tropospheric oxidant (Martin et al., 2003). Understanding the climatological characteristics of tropospheric ozone production and fluxes in subtropical regions is important for assessing ozone's direct effect on climate (Watson et al., 2001; Pachauri and Reisinger, 2007) and its role in atmospheric chemistry on both regional and global scales. The tropospheric ozone budget is influenced by transport from the stratosphere and in situ photochemical production associated with ozone precursors emitted by anthropogenic activity, biomass burning and lightning (Stevenson et al., 2006).

The purpose of this paper is to present a climatology and trends of tropospheric ozone in the Southwestern Indian Ocean (Reunion Island) and South Africa (Irene and Johannesburg). 
Reunion island $\left(20.8^{\circ} \mathrm{S}, 55.5^{\circ} \mathrm{E}\right)$ is located near the southern limit of the tropics, in the Indian Ocean, $1000 \mathrm{~km}$ east of Madagascar. For this region, the dynamical mechanisms influencing tropospheric ozone distribution have been documented, including intrusions of stratospheric air masses via tropopause folds (Baray et al., 1998), Rossby wave breaking (Postel and Hitchman, 1999) and mid latitude cut off lows (Baray et al, 2003). A study of the effect of tropical convection on tropospheric ozone has also been reported (Leclair de Bellevue et al.,2006) and showed some differences between the two sites, Reunion and Irene. In addition, photochemical sources have been identified: biomass burning activity in Southern Africa and Madagascar during austral spring associated with long range transport of air masses are a cause of tropospheric ozone increase over Reunion Island (Baldy et al., 1996; Taupin et al., 2002). At this site, the influence of biomass burning activity has been identified between 5 and $12 \mathrm{~km}$ on tropospheric ozone profiles (Randriambelo et al., 2000).

Johannesburg $\left(26.1^{\circ} \mathrm{S}, 28.0^{\circ} \mathrm{E}\right)$ and Irene $\left(25.9^{\circ} \mathrm{S}\right.$, $28.22^{\circ} \mathrm{E}$ ) are located about $3000 \mathrm{~km}$ southwest of Reunion, closer to ozone precursor sources. From a dynamical perspective, the site of Irene is less affected by tropical convection but more affected by the subtropical jet stream activity than Reunion.

A tropical ozone climatology has been established by Thompson et al. (2003) using SHADOZ network data, and Diab et al. (2004) focused their study on Irene and Johannesburg sites. Climatologies of stratospheric intrusions have been conducted over the Pacific and Atlantic Oceans by Waugh and Polvani (2000) and at a global scale by James et al. (2003). However, the ozone climatology and the long term trends have not been analyzed using the same approach at two tropical/subtropical sites in the region of Southern Africa and the Western Indian Ocean; this is the objective of the present study.

A wide range of ozone data is available at Reunion and Irene. In addition to ozonesonde profiles, in-situ measurements from commercial aircraft (MOZAIC data) and vertical ozone profiles from LIDAR will be used. This dataset is presented in Sect. 2. Section 3 focuses on the geophysical context for each site and the regional sources of ozone precursors. In the fourth Section, we 1) examine and compare all datasets in order to ensure the consistency between the various measurement techniques; 2) present the monthly mean ozone distributions and 3) calculate long term ozone trends. In Sect. 5 we discuss the influence of data sampling and bias on LIDAR and ozonesonde ozone values above Reunion, and discuss possible causes of the seasonal ozone variation and long term ozone trends above both sites.

\section{Instrumentation and dataset features}

\subsection{Ozonesondes}

An ozonesonde program began in 1992 at Reunion and the dataset now includes 17 years of usable data. At Irene, ozonesondes were regularly launched between July 1990 and October 1993 (Diab et al., 2004). Since 1998, when the two sites joined the SHADOZ program (Thompson et al., 2003), ozonesondes are launched regularly on a weekly basis. At Reunion, profiles are collected regularly each week and the frequency of soundings is less affected by weather considerations than by possible technical issues. At Reunion and Irene, the total number of profiles over the 8-year period ranges, respectively, between 13 and 28 profiles per month and between 13 and 20 profiles per month (Fig. 3).

The SHADOZ program aims to provide a consistent dataset of tropospheric and stratospheric ozone in the Southern Hemisphere. The program originally intended to supplement the sparse amount of tropospheric ozone data in the Southern Hemisphere compared to the abundant data in the Northern Hemisphere. The SHADOZ network involves 15 stations, distributed so as to have good coverage across the tropical and subtropical Southern Hemisphere.

The Irene and Reunion stations use ozonesondes equipped with an Electrochemical concentration cell (ECC) for measuring ozone and Vaisala RS80 radiosondes for measuring temperature, pressure and humidity. The cathode KI solution is $1 \%$ buffered at Irene and $0.5 \%$ buffered at Reunion. The vertical extension of profiles range from ground level $(24 \mathrm{~m}$ at Reunion, $1524 \mathrm{~m}$ at Irene) up to burst altitude, which is located between $30 \mathrm{~km}$ and $35 \mathrm{~km}$ in most cases. Smit et al. (2007) evaluate ECC-sonde precision to be better than $\pm(3-5) \%$ and accuracy about $\pm(5-10) \%$ below $30 \mathrm{~km}$ altitude. Further details about ozonesonde precision and accuracy can be found in Smit et al. (2007), who compared the performances of SPC-6A and ENSCI-Z ozonesondes. Since 2007, horizontal wind measurements have been made at Reunion by GPS, simultaneously with ozone and PTU measurements.

In this article, the climatological study (Figs. 4, 5) focuses on 8 common years of data (1998-2006, Table 1) for the two sites. With a considerable number of profiles (Table 1), the ozone climatology benefits from a greater regularity in the ozonesonde time distribution during this period. The trend section uses the whole dataset for the two sites in order to examine the longest possible time period.

\subsection{LIDAR}

Two LIDAR (Light Detection And Ranging) instruments are in operation at Reunion. One of them, devoted to measurement of tropospheric ozone profiles, has been operating since 1998. The approach is to process the differential absorption of two UV wavelengths ( $289 \mathrm{~nm}$ and $316 \mathrm{~nm}$ ) generated by a 
Table 1. Features of the dataset: period of measurements, total number of ozone profiles and altitude range used for climatology and trend studies in Sect. 4.

\begin{tabular}{lcccc}
\hline & & $\begin{array}{c}\text { Time range/number } \\
\text { of years of data }\end{array}$ & $\begin{array}{c}\text { Total number } \\
\text { of profiles }\end{array}$ & $\begin{array}{c}\text { vertical } \\
\text { range of data }\end{array}$ \\
\hline Reunion & Radiosonde - Trends & $1992-2008 / 17$ years & 399 & \\
& Radiosonde - Climatology & $1998-2006 / 8$ years & 269 & sea level-30 km \\
Irene & LIDAR - Climatology & $1998-2006 / 8$ years & 265 & $3 \mathrm{~km}-16 \mathrm{~km}$ \\
\multirow{2}{*}{ Johannesburg } & Radiosonde - Trends & $1990-2008 / 15$ years & 384 & $1524 \mathrm{~m}-30 \mathrm{~km}$ \\
& Radiosonde - Climatology & $1998-2006 / 8$ years & 208 & \\
& MOZAIC - Climatology & $1995-2003 / 9$ years & 577 & $1 \mathrm{~km}-12 \mathrm{~km}$ \\
\hline
\end{tabular}

high pressure deuterium cell. LIDAR profiles are taken several times a week with a $150 \mathrm{~m}$ vertical resolution between $3 \mathrm{~km}$ and the tropical tropopause height of $17 \mathrm{~km}$. The limits of the vertical domain for each profile are closely related to the atmospheric conditions. Details on the DIAL ozone LIDAR at Reunion are given in Baray et al. (1999) and on all the instrumentation of OPAR (Observatoire de Physique de l'Atmosphère de la Reunion) in Baray et al. (2006).

\subsection{MOZAIC}

The MOZAIC program (Measurement of Ozone and Water Vapour by Airbus In-Service Aircraft) was launched in 1994 by European scientists, Airbus and several commercial airlines in order to collect ozone water vapour, carbon monoxide and total odd nitrogen $\left(\mathrm{NO}_{\mathrm{y}}\right)$ data to validate global chemistry transport models (Marenco et al., 1998; Thouret et al., 1998). The program uses equipment installed aboard long haul Airbus A340 aircraft flying from Europe, and the data have recently been used to derive an ozone climatology of the upper troposphere (9-12 km) (Thouret et al., 2006). The accuracy of the ozone measurements is evaluated at \pm 2 ppbv $\pm 2 \%$ (Marenco et al., 1998; Thouret et al., 2006). The MOZAIC data used in this paper include 577 flights to and from Johannesburg between July 1995 and January 2003. The monthly distribution is given in Fig. 3 .

MOZAIC and LIDAR datasets contain a great number of profiles, 577 and 265 profiles, respectively (Fig. 3, Table 1), but the profiles are sporadically distributed in time compared to the SHADOZ data.

\section{Geophysical context and regional sources of ozone precursors}

\subsection{Reunion Island}

\subsubsection{Dynamical context}

Reunion is located in the subsidence region of the Southern Hemisphere Hadley cell. The island meteorology is subject to subtropical, tropical and temperate influences of the general circulation. The South Indian Ocean anticyclone, and perturbations carried in the westerlies affect the island (Randriambelo et al., 2003). The influence of the subtropical jet stream on the island is at a maximum during winter. In Fig. 2a mean zonal wind profiles derived from one year of GPS sonde data between August 2007 and March 2008 at Reunion are presented. A maximum is observed during austral winter. This maximum is consistent with the vicinity of the subtropical jet at this time of year (Fig. 2b). For more details about the dynamical context of the region, PrestonWhyte and Tyson (1988) have documented the circulation patterns in South Africa and the adjacent Atlantic and Indian Oceans.

Ozone increases due to stratospheric intrusions have been detected in South Africa and over the Indian Ocean. These intrusions take place in association with meteorological disturbances such as tropopause folds induced by the subtropical jet stream, cut off lows, tropical cyclones (Baray et al., 1998, 1999, 2003), westerly waves and frontal zones. According to James et al.'s climatology (2003) stratospheric intrusions in the southern subtropical region maximise during austral winter.

\subsubsection{Regional sources}

Of the two types of ozone sources already described, the photochemical source of ozone influencing the ozone profile over Reunion is mainly due to the long range transport of ozone precursors from biomass burning activity in Southern Africa and Madagascar (Fig. 1). Southern Africa is one of the main biomass burning regions in the Southern Hemisphere. The burning season starts in July and ends in October (Marenco et al., 1990). Measurement campaigns such as TROPOZ (TROPospheric Ozone) (Marenco et al., 1990), SAFARI (Southern African Fire-Atmosphere Research Initiative) (Andreae et al., 1996), TRACE-A (Transport and Atmospheric Chemistry near the Equator-Atlantic) (Andreae et al., 1996), and SAFARI 2000 (Swap et al., 2003) have been undertaken in order to study the atmospheric photochemistry and the circulation patterns leading to the redistribution of southern African emissions and resulting in an increase over 


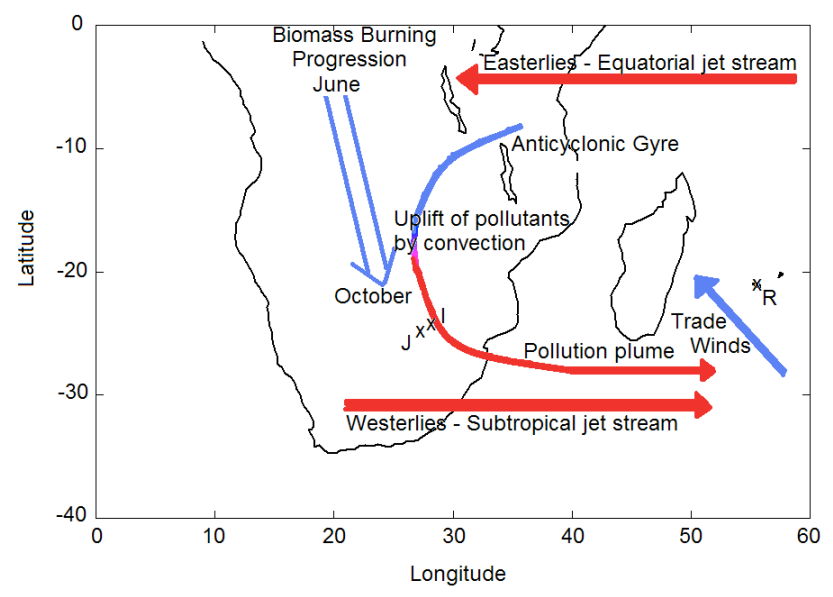

Fig. 1. Schematic representation of meteorological processes affecting tropospheric ozone over subequatorial Africa (Diab et al., 2004). Industrial, biomass burning, and biogenic sources of ozone precursors are also shown. The locations of Johannesburg, Irene, and Reunion are represented by "J","I", and "R", respectively.

Southern Africa and the South Atlantic and Indian Oceans (Randriambelo et al., 1999). Aghedo et al. (2007) recently determined that $70 \%$ of the tropospheric ozone produced by African emissions is exported outside the continent. Meteorological analysis based on trajectory statistics showed that a large part of African emissions might be advected to the Indian Ocean (Garstang et al., 1996; Piketh et al., 2002). Mechanisms responsible for regional dispersion of biomass burning emissions have been documented (Baldy et al., 1996; Taupin et al., 1999, 2002). A climatology by Randriambelo et al. (1999) based on ozonesonde and satellite data focuses on the relative importance of the different mechanisms.

\subsection{Irene}

\subsubsection{Dynamical context}

The atmospheric circulation at Irene $\left(25.9^{\circ} \mathrm{S}, 28.22^{\circ} \mathrm{E}\right)$ is dominated by the subtropical anticyclone within which subsidence and recirculation cause the accumulation of pollutants on large temporal and spatial scales (Garstang et al., 1996; Tyson et al., 1996; Piketh et al., 2002). As a consequence, a $5 \mathrm{~km}$ deep haze layer forms over South Africa, capped by a persistent subsidence inversion (Cosijn and Tyson, 1996). The frequency of this anticyclonic circulation is higher during winter (79\% in June, July) than during summer (11\% in December) (Tyson and Preston-Whyte, 2000). The system is disrupted when a mid-latitude westerly wave crosses the south of South Africa. As a result trace gases including ozone precursors and aerosols circulate inside the stable layer until they are finally released eastward as a giant plume centred at $31^{\circ} \mathrm{S}$ along the east coast (Tyson et al., 1996).
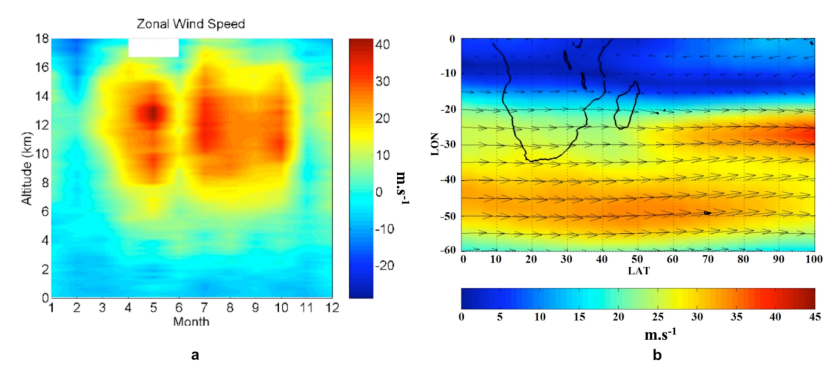

Fig. 2. (a) Zonal wind speed between August 2007 and September 2008 at Reunion from GPS sonde data. (b) Mean austral winter wind fields at $300 \mathrm{hPa}$ derived from NCEP data (1984-2004).

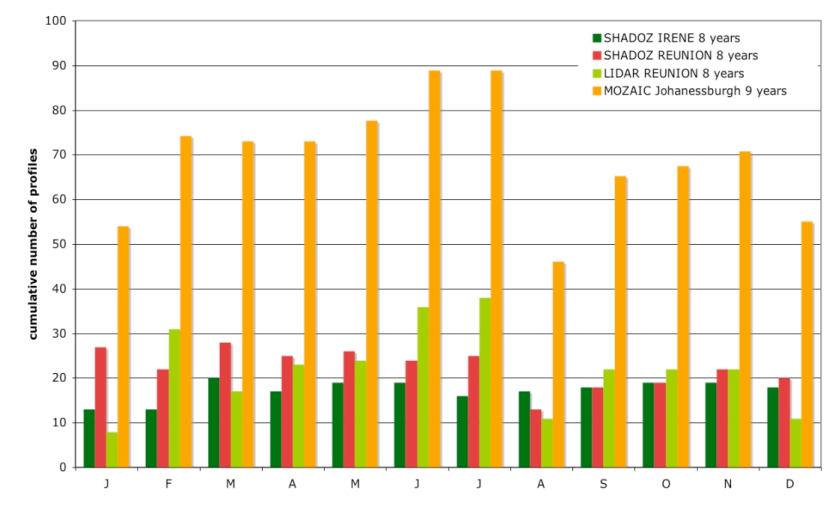

Fig. 3. Cumulative monthly distribution of profiles for each type of data.

\subsubsection{Regional Sources}

In addition to stratospheric sources, ozone in the region surrounding Irene is produced photochemically from biomass burning, biogenic and anthropogenic emissions as well as lightning $\mathrm{NO}_{\mathrm{x}}$ emissions (Aghedo et al., 2007). The emission of VOCs significantly influences atmospheric chemistry because of their high reactivity and result in the formation (or destruction) of tropospheric ozone in high (or low) $\mathrm{NO}_{\mathrm{x}}$ conditions (Aghedo et al., 2007). Volatile Organic Compounds (VOCs) are also naturally emitted by vegetation (Kesselmeier and Staudt, 1999).

Irene is located southwards of the main biomass burning region in Africa (Fig. 1). The biomass burning area extends between $10^{\circ} \mathrm{N}$ and $20^{\circ} \mathrm{S}$ and eastward, up to $25^{\circ} \mathrm{E}$, during the dry season from June to October. Although the strongest ozone enhancement is expected north of Irene, the impact of biomass burning can be detected at the station as a result of long range transport in the anticyclonic gyre. Results of the SAFARI 2000 campaign emphasize the importance of biomass burning in the tropospheric ozone budget of South Africa (Swap et al., 2003). 

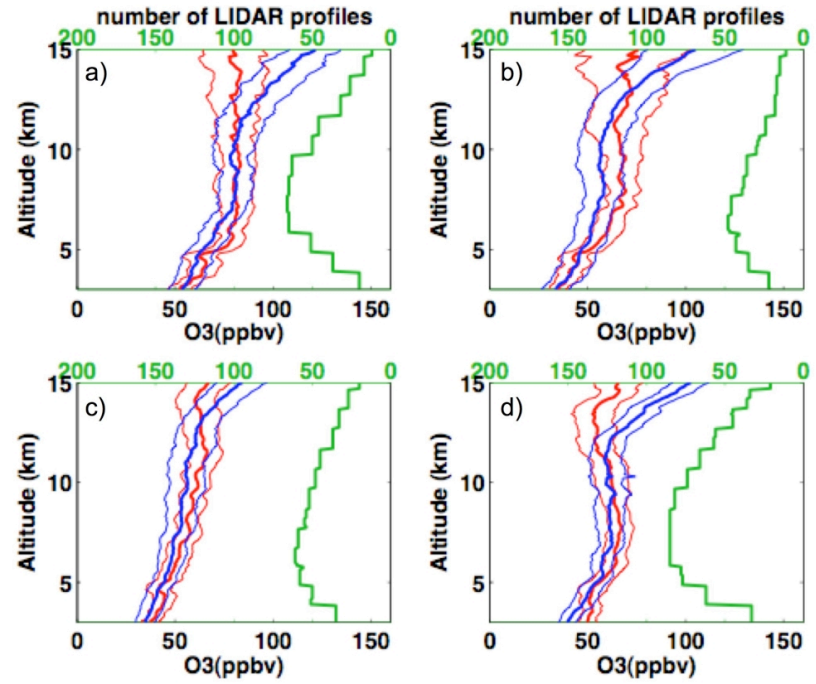

Fig. 4. Seasonal ozone profiles and standard deviation (ppbv) between 3 and $15 \mathrm{~km}$ derived from ozonesonde data (blue lines) and from LIDAR data (red lines) at Reunion during (a) spring (SON) (b) summer (DJF) (c) autumn (MAM) and (d) winter (JJA). The number of profiles used for each DIAL LIDAR climatological profile is given on the right in green.

During summer, the tropical easterlies from the Indian Ocean cause moist air to be advected over Irene. Strong convective activity is a daily phenomenon and can promote rapid vertical uplift of surface pollutants, which leads to an ozone enhancement in the mid- to upper troposphere (Ziemke et al., 2009). Lightning from these convective storms can also be responsible for an increase in tropospheric ozone via ozone production from lightning $\mathrm{NO}_{\mathrm{x}}$ emissions (Schumann and Huntrieser, 2007). Collier et al. (2006) state that South Africa and Madagascar lightning activity maximise during austral spring and summer.

Anthropogenic emissions of ozone precursors are an important factor in the ozone budget. Irene is located close to two urban-industrial areas: Pretoria and Johannesburg. The station is also $100 \mathrm{~km}$ downwind from the main power generating area of South Africa, with 11 large coal-fired power plants (Diab et al., 2004). Domestic use of biofuels also contributes to ozone precursors. The GEIA inventory (Benkovitz et al., 1996) evaluates South Africa's $\mathrm{NO}_{\mathrm{x}}$ emissions as $1.8 \%$ of global anthropogenic emissions, and according to Wells et al. (1996) and Held and Mphepya (2000), 91\% of the South African $\mathrm{NO}_{\mathrm{x}}$ emissions originate from industry.

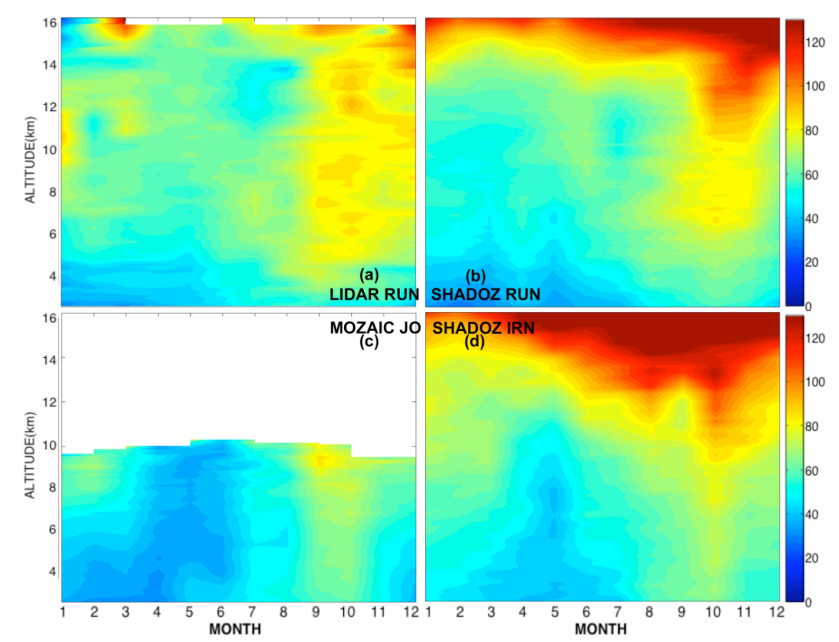

Fig. 5. Monthly distribution of the mean tropospheric ozone mixing ratio (0-130 ppbv) between 3 and $16 \mathrm{~km}$ altitude for different sites and different types of data. (a) LIDAR Reunion, (b) SHADOZ Reunion, (c) MOZAIC Johannesburg, (d) SHADOZ Irene.

\section{Climatology and trends: results}

4.1 Comparison of LIDAR and sonde climatological ozone profiles at Reunion

The mean seasonal vertical distribution of ozone and standard deviations at Reunion (Fig. 4) have been derived from LIDAR data (red lines) and from ozonesonde data (blue lines). Panels (a) to (d) depict austral spring, summer, autumn and winter seasons, respectively. Seasonal profiles derived from the two datasets have similar values between $3 \mathrm{~km}$ and $11 \mathrm{~km}$ for winter and spring, and in autumn the greatest agreement is between 3 and $13 \mathrm{~km}$. LIDAR seasonal profiles show lower ozone mixing ratios than ozonesonde profiles above $11 \mathrm{~km}$ for spring and winter, and above $13 \mathrm{~km}$ for autumn and summer. This difference which appears in the climatology is not found during simultaneous measurements (Baray et al., 1999).

In summer, ozonesonde and LIDAR measurements are consistent in the lower troposphere below $5 \mathrm{~km}$. Above $13 \mathrm{~km}$, in summer (and all seasons) the LIDAR climatology yields smaller values than the ozonesonde profiles. Between $5 \mathrm{~km}$ and $13 \mathrm{~km}$ in summer, the LIDAR profile shows higher values than the sounding profile. The maximum difference between the two profiles in this altitude range is $13 \mathrm{ppbv}$ at $9.5 \mathrm{~km}$.

\subsection{Ozone monthly mean distribution}

LIDAR and ozonesonde data from 1998 to 2006 and 9 years of MOZAIC data have been processed to obtain the mean monthly ozone profile mixing ratios in the troposphere as shown in Fig. 5 between 3 and $16 \mathrm{~km}$. Panels (a) to (d) 
Table 2. Trend values calculated at Reunion and Irene, in DU by decade and the equivalent in percentage per decade, for total tropospheric columns, for the lower $(2-4 \mathrm{~km})$, middle $(2-4 \mathrm{~km})$ and upper troposphere $(10-16 \mathrm{~km})$ and for each season. The lower limit $L$ is $1 \mathrm{~km}$ for Reunion Island and $2 \mathrm{~km}$ for Irene. The data time range is mentioned after the site name. Non statistically significant trends are in italic.

\begin{tabular}{|c|c|c|c|c|c|c|}
\hline \multirow{2}{*}{$\begin{array}{c}\text { Altitude } \\
\text { range }(\mathrm{km}), \\
\text { Season }\end{array}$} & \multicolumn{2}{|c|}{ Reunion 1992-2008 } & \multicolumn{2}{|c|}{ Irene 1990-2008 } & \multicolumn{2}{|c|}{ Irene 1998-2008 } \\
\hline & $\begin{array}{c}\text { Slope } \\
\text { (DU/decade) }\end{array}$ & $\begin{array}{c}\text { Slope } \\
\text { (\%/decade) }\end{array}$ & $\begin{array}{c}\text { Slope } \\
\text { (DU/decade) }\end{array}$ & $\begin{array}{c}\text { Slope } \\
\text { (\%/decade) }\end{array}$ & $\begin{array}{c}\text { Slope } \\
\text { (DU/decade) }\end{array}$ & $\begin{array}{c}\text { Slope } \\
\text { (\%/decade) }\end{array}$ \\
\hline L-16 & $1.94 \pm 1.81$ & $5.67 \pm 5.28$ & $1.81 \pm 0.97$ & $5.21 \pm 2.78$ & $2.47 \pm 3.01$ & $6.93 \pm 8.44$ \\
\hline $2-4$ & $0.01 \pm 0.37$ & $0.12 \pm 6.91$ & $0.93 \pm 0.26$ & $14.37 \pm 4.01$ & $2.08 \pm 0.86$ & $30.45 \pm 12.52$ \\
\hline $4-10$ & $0.70 \pm 0.93$ & $4.37 \pm 5.81$ & $0.63 \pm 0.52$ & $3.99 \pm 3.31$ & $1.11 \pm 1.56$ & $6.91 \pm 9.67$ \\
\hline $10-16$ & $1.31 \pm 0.62$ & $12.34 \pm 5.82$ & $0.24 \pm 0.44$ & $1.92 \pm 3.51$ & $-0.61 \pm 1.45$ & $-4.82 \pm 11.43$ \\
\hline L-16, DJF & $1.38 \pm 3.12$ & $4.55 \pm 10.32$ & $2.41 \pm 1.95$ & $7.16 \pm 5.79$ & $1.60 \pm 6.13$ & $4.61 \pm 17.62$ \\
\hline $2-4$, DJF & $-0.40 \pm 0.65$ & $-9.34 \pm 15.20$ & $1.31 \pm 0.57$ & $20.53 \pm 9.03$ & $2.04 \pm 1.83$ & $29.48 \pm 26.46$ \\
\hline $4-10, \mathrm{DJF}$ & $0.45 \pm 1.66$ & $3.15 \pm 11.76$ & $0.99 \pm 1.17$ & $6.22 \pm 7.39$ & $0.16 \pm 3.65$ & $0.96 \pm 22.33$ \\
\hline 10-16, DJF & $1.58 \pm 1.32$ & $16.07 \pm 13.43$ & $0.25 \pm 0.63$ & $2.19 \pm 5.49$ & $-0.25 \pm 1.96$ & $-2.14 \pm 16.86$ \\
\hline L-16, MAM & $0.20 \pm 2.47$ & $0.69 \pm 8.57$ & $0.43 \pm 1.10$ & $1.46 \pm 3.70$ & $1.22 \pm 3.37$ & $4.08 \pm 11.25$ \\
\hline 2-4, MAM & $-0.18 \pm 0.45$ & $-4.00 \pm 10.13$ & $0.71 \pm 0.31$ & $12.99 \pm 5.67$ & $2.12 \pm 1.24$ & $36.38 \pm 21.17$ \\
\hline 4-10, MAM & $0.38 \pm 1.32$ & $2.84 \pm 9.93$ & $-0.11 \pm 0.68$ & $-0.85 \pm 5.14$ & $-1.16 \pm 2.115$ & $-8.71 \pm 15.88$ \\
\hline 10-16, MAM & $0.38 \pm 0.93$ & $4.12 \pm 10.15$ & $-0.14 \pm 0.61$ & $-1.25 \pm 5.58$ & $0.54 \pm 2.14$ & $5.02 \pm 19.80$ \\
\hline L-16, JJA & $4.14 \pm 3.70$ & $11.95 \pm 10.67$ & $3.12 \pm 1.74$ & $9.18 \pm 3.70$ & $14.98 \pm 13.77$ & $5.50 \pm 4.82$ \\
\hline $2-4$, JJA & $0.12 \pm 0.88$ & $2.10 \pm 15.69$ & $0.69 \pm 0.52$ & $11.51 \pm 5.67$ & $1.98 \pm 1.63$ & $31.55 \pm 25.92$ \\
\hline 4-10, JJA & $2.00 \pm 1.97$ & $12.34 \pm 12.17$ & $1.70 \pm 0.88$ & $11.39 \pm 5.14$ & $4.40 \pm 2.17$ & $28.26 \pm 13.95$ \\
\hline 10-16, JJA & $1.86 \pm 0.97$ & $18.30 \pm 9.51$ & $0.73 \pm 1.08$ & $5.57 \pm 5.58$ & $-1.08 \pm 3.40$ & $-7.99 \pm 25.11$ \\
\hline L-16, SON & $2.69 \pm 2.47$ & $6.18 \pm 5.69$ & $2.70 \pm 1.66$ & $6.55 \pm 4.02$ & $5.50 \pm 4.82$ & $12.99 \pm 11.39$ \\
\hline $2-4, \mathrm{SON}$ & $0.40 \pm 0.50$ & $5.71 \pm 7.21$ & $1.17 \pm 0.49$ & $14.96 \pm 6.22$ & $2.39 \pm 1.49$ & $28.89 \pm 18.08$ \\
\hline $4-10, \mathrm{SON}$ & $0.45 \pm 1.30$ & $2.20 \pm 6.34$ & $0.77 \pm 0.96$ & $4.04 \pm 5.04$ & $2.70 \pm 2.69$ & $13.98 \pm 13.95$ \\
\hline $10-16$, SON & $1.58 \pm 1.10$ & $11.84 \pm 8.25$ & $0.76 \pm 0.84$ & $5.33 \pm 5.85$ & $0.41 \pm 2.81$ & $2.80 \pm 19.06$ \\
\hline
\end{tabular}

depict LIDAR data, SHADOZ data from Reunion, MOZAIC data from Johannesburg, and SHADOZ data from Irene respectively. The lower altitude limit of $3 \mathrm{~km}$ is imposed by the LIDAR data; and $16 \mathrm{~km}$ is below the tropopause height: Sivakumar et al. (2006) located the mean altitudes of the lapse rate tropopause and the cold point tropopause respectively at $17 \mathrm{~km}$ and $16 \mathrm{~km}$ of altitude at Reunion from 13 years of ozonesonde data.

Each data type shows a springtime maximum. The greatest values are found in the SHADOZ data (Panels b, d), and Irene data shows values greater than $90 \mathrm{ppbv}$ above $10 \mathrm{~km}$. MOZAIC and LIDAR data also exhibit a springtime peak but the ozone mixing ratios are seldom above $80 \mathrm{ppbv}$ in the lower and mid-troposphere above Johannesburg.

The LIDAR ozone mixing ratio at Reunion (Panel a) shows greater values in January than the mixing ratio derived from SHADOZ data. Specifically LIDAR data display ozone values varying between 80 and $90 \mathrm{ppbv}$ between 9 and $12 \mathrm{~km}$. For the same altitude, the SHADOZ ozone mixing ratio has values between 50 and $70 \mathrm{ppbv}$. This result is consistent with summer seasonal profiles shown in the previous section.

Upper tropospheric ozone mixing ratios at Irene are greater than at Reunion. During winter, the ozonopause is lower at Irene, with the $100 \mathrm{ppbv}$ ozone contour about 1$2 \mathrm{~km}$ lower above Irene than Reunion.
During summer, values above $70 \mathrm{ppbv}$ are found at Irene at $10 \mathrm{~km}$ altitude and above. At Reunion, such values are not recorded below an altitude of $11 \mathrm{~km}$. The MOZAIC and SHADOZ plots for South Africa show an ozone enhancement in the mid-troposphere where values exceed $60 \mathrm{ppbv}$ up to the end of summer (January-February).

\subsection{Long-term Tropospheric ozone behaviour at Reunion} Island and Irene based on linear trend calculations

In this section, we examine the linear trends of the complete ozone datasets of Reunion Island and Irene which cover the periods 1992-2008 and 1990-2008 respectively, with a gap of data for Irene between 1994 and 1998. Hence the trends for Irene have been calculated for both the 1990-2008 and the 1998-2008 datasets, however in this paper we focus mainly on the longest time period. We also calculated ozone trends for different tropospheric layers above the two measurement sites (Table 2).

To examine the linear trend, the following equation is used:

Ozone $=\tau t+\beta$

$\tau$ is the linear trend calculated by linear regression using the least squares method, $t$ is the time and $\beta$ is the $y$-intercept. The error is calculated using the student's t-test with $95 \%$ 

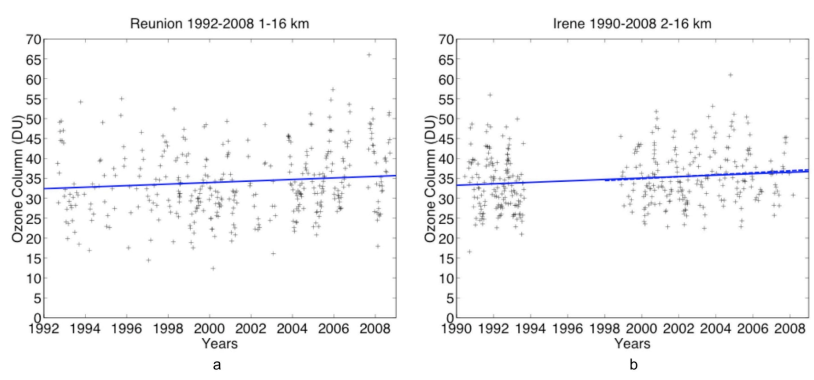

Fig. 6. Ozone trends for the tropospheric layer between 1 and $16 \mathrm{~km}$ at Reunion (a) and between 2 and $16 \mathrm{~km}$ at Irene (b). The dashed line shows the trend at Irene calculated from the 1998-2008 dataset.

confidence interval. This error gives a statistical estimation of the influence of the variability of ozone data on the estimation of the linear trend (Montgomery et al., 2006). Ozone trends have been calculated in atmospheric layers in DU per decade $\left(1 \mathrm{DU}=2.69 \times 10^{16} \mathrm{molec} / \mathrm{cm}^{2}\right)$ and in $\%$ per decade (Table 2).

Ozone trends calculated at Reunion and Irene are presented in Fig. 6. The lower limit of the tropospheric column is $1 \mathrm{~km}$ at Reunion, and $2 \mathrm{~km}$ at Irene, because of the different altitudes of the two sites. The upper limit has been fixed at $16 \mathrm{~km}$, below the tropical tropopause height (Sivakumar et al., 2006). Considering the whole column, the tropospheric trend is positive $(1.94 \pm 1.81 \mathrm{DU} /$ decade) for Reunion, and for Irene ( $1.81 \pm 0.97 \mathrm{DU} /$ decade).

In order to examine the potential influence of the two main sources of ozone in the region, viz. anthropogenic and biomass burning pollution of the lower layers and stratosphere-troposphere exchange, the troposphere has been separated into three layers: one below $4 \mathrm{~km}$, the altitude where the trade wind inversion occurs (Taupin et al., 1999), and the free troposphere which is separated into two equal parts: the mid-troposphere between 4 and $10 \mathrm{~km}$ and the upper troposphere between 10 and $16 \mathrm{~km}$.

Some differences between the two sites appear (Fig. 7, Table 2):

- The trend for the lower layer at Irene is clearly positive $(0.93 \pm 0.26 \mathrm{DU} / \mathrm{decade})$, while at Reunion no trend is observed.

- The trend for the mid-troposphere at Irene is positive $(0.63 \pm 0.52 \mathrm{DU} / \mathrm{dec}$ ade) but less than the layer below. The weaker trend $(0.24 \pm 0.44 \mathrm{DU} /$ decade $)$ observed in the upper troposphere is not significant. For Reunion, the trend behaviour is opposite: the mid-troposphere trend is positive but not statistically significant $(0.70 \pm 0.93 \mathrm{DU} /$ decade). The stronger trend is observed in the upper troposphere ( $1.31 \pm 0.62 \mathrm{DU} /$ decade) .
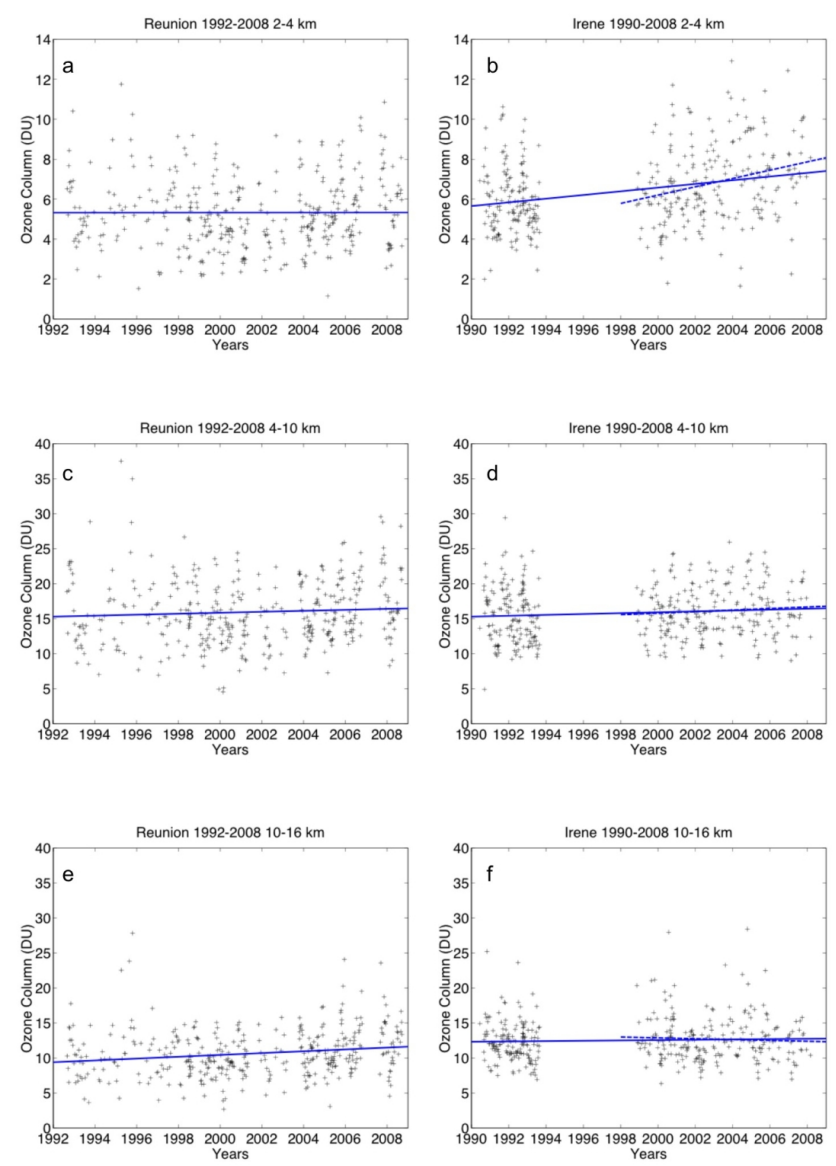

Fig. 7. Ozone trends between 2 and $4 \mathrm{~km}$ at Reunion (a) and Irene (b), between 4 and $10 \mathrm{~km}$ at Reunion (c) and Irene (d), and between 10 and $16 \mathrm{~km}$ at Reunion (e) and Irene (f). The dashed lines show trends at Irene calculated from the 1998-2008 dataset.

To investigate further the influence of the stratospheric and photochemical mechanisms, seasonal trends are presented in Fig. 8 for Reunion and Fig. 9 for Irene. Table 2 shows the seasonal trends for each tropospheric layer at the two sites.

The total tropospheric column shows no significant trend for the two sites during the March-April-May (MAM) season.

For Reunion, the most positive trends have been observed in September-October-November (SON) $(2.69 \pm 2.47 \mathrm{DU} /$ decade) and maximise in June-JulyAugust (JJA) (4.14 $\pm 3.70 \mathrm{DU} /$ decade). The stronger trend during SON is located in the upper troposphere and during $\mathrm{JJA}$, in the mid and upper troposphere.

In contrast, for Irene, the trend is strong in SON $(2.70 \pm 1.66 \mathrm{DU} / \mathrm{dec}$ ade $)$, and also in December-JanuaryFebruary (DJF) $(2.41 \pm 1.95$ DU/decade), both with higher values in the lower troposphere, and in JJA $(3.12 \pm 1.74 \mathrm{DU} /$ decade) the trend maximise between $4 \mathrm{~km}$ and $10 \mathrm{~km}$. 

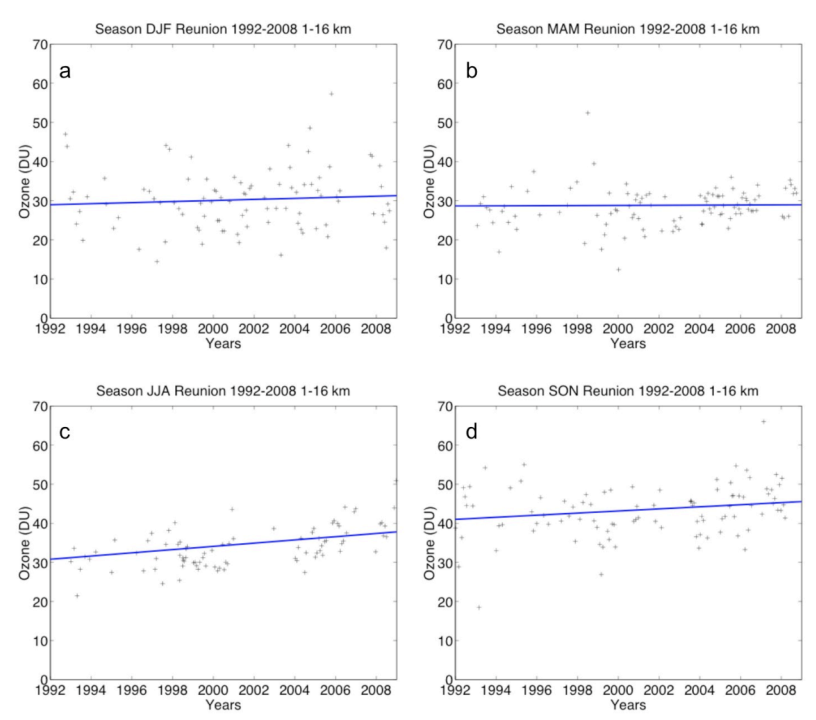

Fig. 8. Ozone trends for the tropospheric layer between 1 and $16 \mathrm{~km}$ at Reunion in December-January-February (a), March-April-May (b), June-July-August (c), et September-October-November (d).

\section{Discussion}

5.1 Comparison of ozone DIAL and sonde climatological profiles at Reunion

Figure 4 shows that apart from the summer case, the seasonal profiles of tropospheric ozone derived from LIDAR and ozonesonde data are in agreement between $3 \mathrm{~km}$ and $11 \mathrm{~km}$ to $13 \mathrm{~km}$ according to the season. Within this range of altitude, LIDAR and ozonesonde data have the same climatological value for austral spring, autumn and winter.

LIDAR profiles show for all seasons lower ozone mixing ratio than the ozonesonde profiles in the upper troposphere. Because of the absorption of the LIDAR beam by ozone molecules, when the LIDAR signal is weakened in the upper part of the profiles, the vertical limits of LIDAR ozone profiles are often below an altitude where high ozone mixing ratios are found. Therefore, the number of profiles used to build the climatological values are fewer in the upper troposphere and profiles with high ozone mixing ratio in the upper troposphere are small in number in the LIDAR dataset. Contrary to the LIDAR technique, the measurement of ozone by ozonesondes is not affected by the amount of ozone. This gives rise to some differences in the upper tropospheric climatology. The upper tropospheric DIAL ozone climatology is not representative of the true ozone climatology, despite individual DIAL profiles extending through the whole troposphere being available.

Finally, we observe that the LIDAR summer profile shows more ozone than the ozonesonde summer profile between $5 \mathrm{~km}$ and $13 \mathrm{~km}$. The difference observed is comparable to the difference between the two ozone climatological
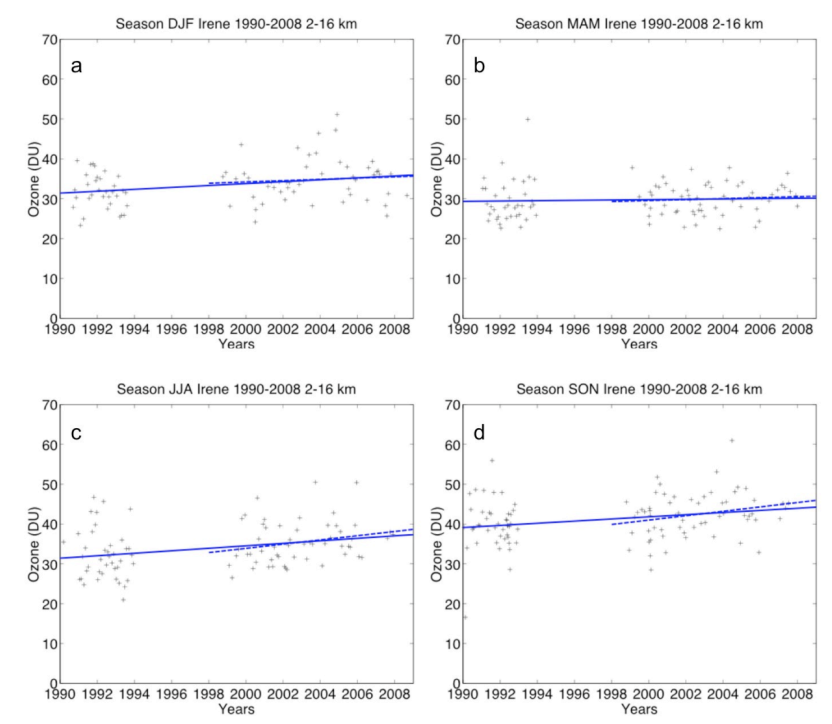

Fig. 9. Same as Fig. 8 but between 2 and $16 \mathrm{~km}$ at Irene. The dashed lines show trends at Irene calculated from the 1998-2008 dataset.

profiles obtained in the presence and absence of tropical convection (Fig. 4 of Leclair de Bellevue et al., 2006). While ozonesonde measurements can be performed in broad weather conditions, LIDAR measurements can be performed only during nights and with clear sky conditions. Moreover, summer corresponds to the rainy season at Reunion and convection exerts a complex role on ozone formation and its vertical distribution. Uplift of ozone poor air masses into the troposphere in convective systems results in low values of ozone in the upper troposphere, while deep convection in the vicinity of STE processes along the subtropical jet stream can be associated with ozone enhancement in the mid-troposphere (Leclair de Bellevue et al., 2006).

\subsection{Monthly mean distributions}

Figure 5 shows evidence of a lower ozonopause at Irene during austral winter. Irene is located at $25.9^{\circ} \mathrm{S}$, a more southerly latitude than Reunion $\left(21.0^{\circ} \mathrm{S}\right)$, and consequently experiences a greater influence from the subtropical jet stream during winter than Reunion (Fig. 2). In addition, according to James et al. (2003) the stratospheric intrusions maximise at $30^{\circ} \mathrm{S}$ in the Southern Hemisphere during austral winter. Therefore, the lower position of the ozonopause at Irene is consistent with a strong influence of stratospheric intrusions during winter in South Africa.

During summer, the upper troposphere at Irene shows greater ozone mixing ratios than at Reunion. Irene is located nearer to ozone precursor sources than Reunion. Moreover, during summer South Africa is under the influence of the easterlies, which gives rise to convective activity and allows advection and mixing of tropospheric air masses (Ziemke et al., 2009). Collier et al. (2006) report that lightning $\mathrm{NO}_{\mathrm{x}}$ 
production in south Africa maximises during summer. The quick redistribution of surface pollutants and lightning $\mathrm{NO}_{\mathrm{x}}$ production can be responsible for a mid- and upper tropospheric ozone enhancement.

Considering the South African data for January, the ozone enhancement (above $60 \mathrm{ppbv}$ ) in the mid-troposphere appears to be a continuation of the enhanced mid-tropospheric ozone observed since October. This broad mid-tropospheric ozone enhancement may be due to the transition from a strong stratospheric influence in spring to a photochemical influence in summer. According to Diab (2004) Irene is located in an active urban industrial region. Domestic emissions during summer coupled with convection might explain this phenomenon.

\subsection{Ozone trends}

At Reunion, layers below $4 \mathrm{~km}$ are not directly influenced by biomass burning and stratosphere-troposphere exchange because of the easterly trade wind regime. These layers are only impacted by local sources and transport across the Indian Ocean. At Irene, local sources of pollution and biomass burning can both occur. For the two sites, the two layers 4$10 \mathrm{~km}$ and $10-16 \mathrm{~km}$ can be directly influenced by biomass burning and stratosphere-troposphere exchange.

Irene has a positive trend for the lower layer but this is not the case at Reunion (Table 2). Under the hypothesis of an increase of biomass burning and pollution in South Africa, a positive trend of ozone over South Africa is consistent because of a persistent synoptic recirculation which occurs over South Africa (Preston-Whyte and Tyson, 1988). However, the increase in pollution and biomass burning activity since the 1990s needs to be confirmed by further investigation. On the contrary, lower layers over Reunion are less directly influenced by biomass burning because of the easterly trade wind regime (Baldy et al., 1996).

Regarding the three tropospheric layers, we observe that the trend at Irene decreases with altitude, suggesting that the tropospheric trend at Irene is mainly governed by the lower layers of the troposphere, and specifically by a change in biomass burning and pollution influences.

At Reunion, the strongest trend occurs between $10 \mathrm{~km}$ and $16 \mathrm{~km}$. The reason for this positive trend for the upper layer is an interesting issue and we draw two hypotheses: first, the influence of the increase of biomass burning and pollution can play a role: the trend values in the upper troposphere at Reunion could be related to the complex dynamical mechanisms which are necessary for Reunion Island tropospheric ozone to be influenced by biomass burning: injection of pollutants in the free troposphere by convection, mix-thencook scheme and ozone production during westerly transport (Chatfield and Delany, 1990; Baldy et al., 1996). The second hypothesis is an increase in stratosphere-troposphere exchange which could be induced by climate change.
For the studied sites, it has been established that:

- The influence of biomass burning is at a maximum in SON season (Baldy etal., 1996; Randriambelo et al., 2000).

- The influence of stratosphere-troposphere exchange induced by the subtropical jet stream is at a maximum in JJA, because of the location of the jet stream close to the latitude of Reunion (Baray et al., 1998; Randriambelo et al., 2000).

- For Reunion, deep convection along the edge of the subtropical jet where stratosphere to troposphere exchange occurs is at a maximum in DJF (Leclair de Bellevue et al., 2006).

- The MAM season could be representative of background ozone levels, since the influences of stratosphere-troposphere exchange and biomass burning are weak.

Taking these considerations into account, the total column seasonal trends (Figs. 8, 9) are discussed.

- The two sites effectively show weak and non significant trends for MAM.

- For Reunion, trends maximise in JJA. This suggests that stratosphere-troposphere exchange is the most important influence as it is the most active ozone source during this season.

- At Irene, trends maximise in SON, DJF and JJA. Stratospheric intrusions and photochemical mechanisms can both play a role in the annual trend observed. An overview of long-term changes in tropospheric ozone has recently been published (Oltmans et al., 2006). This study was based on a global network of observations, with some stations located in the tropical and subtropical regions of the Southern Hemisphere: American Samoa, New Zealand, Australia and South Africa. For Cape Grimm (Australia) and Lauder (New Zealand), Oltmans et al. (2006) observe no change in the surface trend in summer, but a significant increase during the late winter and early spring. For Lauder (New Zealand), they show an interesting vertical structure of the ozone trends, positive below $500 \mathrm{hPa}$, and slightly negative above the $500 \mathrm{hPa}$ level (but not significant), very similar to the vertical structure that we have observed for the ozone trends over Irene. For Cape Point (South Africa) positive surface trends have been observed throughout the year, but the largest trend is again during the late winter and early spring, similar to the trends observed over Irene in our study. For all the sites of the subtropical Southern Hemisphere, Oltmans et al. (2006) point out that the seasonal increase occurs during a time of the year when biomass burning in the Southern Hemisphere is very active. 


\section{Conclusions}

In this study we have presented the climatology of tropospheric ozone in the south-western part of the Indian Ocean (Reunion Island) and South Africa (Irene, Johannesburg), and the tropospheric ozone trends. The comparison of the seasonal profiles of tropospheric ozone of Reunion Island obtained from ozonesondes and LIDAR showed that the two climatological profiles are generally in good agreement, except in austral summer with higher values for the LIDAR profiles in the free troposphere, and lower values in the upper troposphere for all the seasons. Because of the nature of LIDAR retrievals (measurements performed only under clear sky conditions, and an upper limit depending on the signal strength) the LIDAR profile is not representative of the true ozone climatology in the whole troposphere.

Linear trends have been calculated from ozonesonde data at Reunion and Irene. Considering the whole tropospheric column, the trend is positive for the two sites. The trend calculations have been repeated, stratifying the troposphere into three columns, and separating the dataset into seasons. The increase in tropospheric ozone observed over Irene occurs mainly in the lower layers, similar to observations of Oltmans et al. (2006) over other sites of the Southern Hemisphere. It could be associated with an increase in pollution and biomass burning. Our study outlines some differences between Irene and Reunion Island, which has a positive trend in the upper troposphere but not in the lower troposphere, and a stronger trend in winter when stratosphere-troposphere exchange peaks.

Clearly, measurements of other trace gases and detailed modelling studies are required to determine the origin of ozone above these two sites. Our short term intention is to study the temporal and vertical distribution of anomalies in the tropospheric ozone column over Irene and Reunion. In order to discern the influence of different sources, the climatology and trends of tropospheric ozone, as well as CO measurements and the convective transport index from the MOPITT satellite (Deeter et al., 2003) will be analysed. The long term perspective is to provide a complete quantification of all the sources influencing the tropospheric ozone budget in the region using a Lagrangian approach and to compare the results with those obtained from a global chemical transport model.

Acknowledgements. The authors thank the French regional, national (INSU, CNRS) and international (NASA/GFSC) organisations for supporting the OPAR (Observatoire de Physique de l'Atmosphère de la Réunion) station. The regional administration provides funding to $\mathrm{G}$. Clain for her $\mathrm{PhD}$.

We thank the SHADOZ network for the ozonesonde data, in particular G. J. R. Coetzee, Principal Investigator at Irene. We also thank Gérard Ancellet who initiated the tropospheric LIDAR measurements at Reunion. Yann Courcoux, Stéphane Richard and Patrick Hernandez now in charge of LIDAR data also receive our gratitude.
We acknowledge MOZAIC Principal Investigators, Valérie Thouret and Philippe Nédélec for providing the ozone data, as well as the airlines (Lufthansa, Air France and Austria) who carry free of charge the MOZAIC instrumentation and perform the maintenance since 1994.

Finally, we thank the editor Owen Cooper and the two anonymous referees for their constructive remarks which helped us to improve this manuscript.

Edited by: O. Cooper

\section{References}

Aghedo, A. M., Schultz, M. G., and Rast, S.: The influence of African air pollution on regional and global tropospheric ozone, Atmos. Chem. Phys., 7, 1193-1212, 2007, http://www.atmos-chem-phys.net/7/1193/2007/.

Andreae, M. O., Fishman, J., and Lindesay, J.: The Southern Tropical Atlantic Experiment (STARE): Transport and Atmospheric Chemistry near the Equator-Atlantic (TRACE A) and Southern African Fire-Atmosphere Research Initiative (SAFARI): An introduction, J. Geophys. Res., 101, 23519-23520, 1996.

Baldy, S., Ancellet, G., Bessafi, M., Badr, A., and Lan Sun Luk, D.: Field observations of the vertical distribution of tropospheric ozone at the island of Reunion (southern tropics), J. Geophys. Res., 101(D19), 23835-23850, 1996.

Baray, J. L., Ancellet, G., Taupin, F. G., Bessafi, M., Baldy, S., and Keckhut, P.: Subtropical tropopause break as a possible stratospheric source of ozone in the tropical troposphere, J. Atmos. Sol.-Terr. Phy., 60(1), 27-36, 1998.

Baray J. L., Ancellet, G., Randriambelo, T., and Baldy, S.: Tropical cyclone Marlene and stratosphere-troposphere exchange, J. Geophys. Res., 104(D11), 13953-13970, 1999.

Baray, J. L., Leveau, J., Porteneuve, J., Ancellet, G., Keckhut, P., Posny, F., and Baldy, S.: Description and evaluation of a tropospheric ozone LIDAR implemented on an existing LIDAR in the southern subtropics, Appl. Optics, 38(33), 6808-6817, 1999.

Baray, J. L., Baldy, S., Diab, R. D., and Cammas, J. P.: Dynamical study of a tropical cut-off low over South Africa, and its impact on tropospheric ozone, Atmos. Environ., 37(11), 14751488, 2003.

Baray, J. L., Leveau, J., Baldy, S., Jouzel, J., Keckhut, P., Bergametti, G., Ancellet, G., Bencherif, H., Cadet, B., Carleer, M., David, C., De Mazière, M., Faduilhe, D., Godin Beekmann, S., Goloub, P., Goutail, F., Metzger, J. M., Morel, B., Pommereau, J. P., Porteneuve, J., Portafaix, T., Posny, F., Robert, L., and Van Roozendael, M.: An instrumented station for the survey of ozone and climate change in the southern tropics: Scientific motivation, technical description and future plans, J. Environ. Monitor., 8, 1020-1028, doi:10.1039/b607762e, 2006.

Benkovitz, C. M., Scholtz, M. T., Pacyna, J., Tarrason, L., Dignon, J., Voldner, E. C., Spiro, P. A., Logan, J. A., and Graedel, T. E.: Global gridded inventories of anthropogenic emissions of sulfur and nitrogen, J. Geophys. Res., 101, 29239-29254, 1996.

Chatfield, R. B. and Delany, A. C.: Convection links biomass burning to increased tropical ozone: However, models will tend to overpredict $\mathrm{O}_{3}$, J. Geophys. Res., 95, 18473-18488, 1990. 
Collier, A. B., Hughes, A. R. W., Lichtenberger, J., and Steinbach, P.:Seasonal and diurnal variation of lightning activity over southern Africa and correlation with European whistler observations, Ann. Geophys., 24, 529-542, 2006, http://www.ann-geophys.net/24/529/2006/.

Cosijn, C. and Tyson, P. D.: Stable discontinuities in the atmosphere over South Africa, S. Afr. J. Sci., 92, 381-386, 1996.

Deeter, M. N., Emmons, L. K., Francis, G. L., Edwards, D. P., Gille, J. C., Warner, J. X., Khattatov, B., Ziskin, D., Lamarque, J.-F., Ho, S.-P., Yuding, V., Attie, J.-L., Packman, D., Chen, J., Mao, D., and Drummond, J. R.: Operational carbon $\mathrm{moNO}_{\mathrm{x}}$ ide retrieval algorithm and selected results for the MOPITT instrument, J. Geophys. Res., 108(D14), 4399, doi:10.1029/2002JD003186, 2003.

Diab, R. D., Thompson, A. M., Mari, K., Ramsay, L., and Coetzee, G. J. R.: Tropospheric ozone climatology over Irene, South Africa, From 1990 to 1994 and 1998 to 2002, J. Geophys. Res., 109, D20301, doi:10.1029/2004JD004793, 2004.

Garstang, M., Tyson, P. D., Swap, R., Edwards, M., Kalleberg, P., and Lindsay, J. A.: Horizontal and vertical transport of air over Southern Africa, J. Geophys. Res., 101, 23721-23736, 1996.

Gettelman, A., Birner, T., Eyring, V., Akiyoshi, H., Plummer, D. A., Dameris, M., Bekki, S., Lefévre, F., Lott, F., Brühl, C., Shibata, K., Rozanov, E., Mancini, E., Pitari, G., Struthers, H., Tian, W., and Kinnison, D. E.: The Tropical Tropopause Layer 19602100, Atmos. Chem. Phys. Discuss., 8, 1367-1413, 2008, http://www.atmos-chem-phys-discuss.net/8/1367/2008/.

Held, G. and Mphepya, J.: Wet and dry deposition in South Africa, Proceedings, XI Congresso Brasiliero de Meteorologia (CDROM), SBMET, Rio de Janeiro, 16-20 Outubro 2000, Paper QA00002, 2824-2833, 2000.

James, P., Stohl, A., Forster, C., Eckhardt, S., Seibert, P., and Frank, A.: A15-year climatology of stratosphere-troposphere exchange with a Lagrangian particle dispersion model: 1 . Methodology and validation, J. Geophys. Res., 108(D12), 8519, doi:10.1029/2002JD002637, 2003.

Kesselmeier, J. and Staudt, M.: Biogenic volatile organic compounds (VOC): An overview on emission, physiology and ecology, J. Atmos. Chem., 33, 23-88, 1999.

Lacis, A. A., Wuebbles, D. J., and Logan, J. A.: Radiative Forcing of Climate by Changes in the Vertical Distribution of Ozone, J. Geophys. Res., 95(D7), 9971-9981, 1990.

Leclair De Bellevue, J., Réchou, A., Baray, J. L., Ancellet, G., and Diab, R. D.: Signatures of stratosphere to troposphere, transport near deep convective events in the southern subtropics, J. Geophys. Res., 111, D24107, doi:10.1029/2005JD006947, 2006.

Lu, H.-C. and Chang T.-S.: Meteorologically adjusted trends of daily maximum ozone concentrations in Taipei, Taiwan, Atmos. Environ., 39, 6491-6501, 2005.

Marenco, A., Medale, J. C., and Prieur, S.: Study of tropospheric ozone in the tropical belt (Africa, America) from STRATOZ and TROPOZ campaigns, Atmos. Environ. 11, 2823-2834, 1990.

Marenco, A., Thouret, V., Nédélec, P., Smit, H. G., Helten, M., Kley, D., Karcher, F., Simon, P., Law, K., Pyle, J., Poshmann, G., Von Wrede, R., Hume, C., and Cook, T.: Measurement of ozone and water vapor by Airbus in service aircraft: The MOZAIC airborne programme, an overview, J. Geophys. Res., 103, 2563125642, 1998.

Martin, R. V., Jacob, D. J. , Yantosca, R. M., Chin, M., and Ginoux,
P.: Global and regional decreases in tropospheric oxidants from photochemical effects of aerosols, J. Geophys. Res., 108(D3), 4097, doi:10.1029/2002JD002622, 2003.

Montgomery, D. C., Peck, E. A., and Geoffrey Vining, G.: Introduction to Linear Regression Analysis, ISBN:978-0-471-754954, 4th edition, 640 pp., August 2006.

Oltmans, S. J., Lefohn, A. S., Harrisa, J. M., Galbally, I., Scheel, H. E., Bodeker, G., Brunke, E., Claude, H., Tarasick, D., Johnson, B. J., Simmonds, P., Shadwick, D., Anlauf, K., Hayden, K., Schmidlil, F., Fujimoto, T., Akagi, K., Meyer, C., Nichol, S., Davies, J., Redondas, A., and Cuevas, E.: Long-term changes in tropospheric ozone, Atmos. Environ., 40, 3156-3173, 2006.

Pachauri, R. K, Reisinger, A., Albritton, D. L., Barker, T., Bashmakov, I. A., Canziani, O., Christ, R., Cubasch, U., Davidson, O., Gitay, H., Griggs, D., Halsnaes, K., Houghton, J., House, J., Kundzewicz, Z., Lal, M., Leary, N., Magadza, C., McCarthy, J. J., Mitchell, J. F. B., Moreira, J. R., Munasinghe, M., Noble, I., Pachauri, R., Pittock, B., Prather, M., Richels, R. G., Robinson, J. B., Sathaye, J., Schneider, S., Scholes, R., Stocker, T., Sundararaman, N., Swart, R., Taniguchi, T., and Zhou, D.: IPCC, 2007: Climate Change 2007: Synthesis Report, Contribution of Working Groups I, II and III to the Fourth Assessment Report of the Intergovernmental Panel on Climate Change, IPCC, Geneva, Switzerland, 104 pp., 2007.

Piketh, S. J., Swap, R. J., Maenhaut, W., Annegarn, H. J., and Formenti, P.: Chemical evidence of long range atmospheric transport over south Africa, J. Geophys. Res., 107(D24), 4817, doi:10.1029/2002JD002056, 2002.

Postel, G. A. and Hitchman, M. H.: A climatology of Rossby wave breaking along the subtropical tropopause, J. Atmos. Sci., 56, 359-373, 1999.

Preston-Whyte, R. A. and Tyson, P. D.: The atmosphere and weather of Southern Africa, Oxford university press Cape Town, South Africa, 1988.

Randriambelo, T., Baray, J. L., Baldy, S., Bremaud, P., and Cautenet, S.: A case study of extreme tropospheric ozone contamination in the tropics using in-situ, satellite and meteorological data, J. Geophys. Res, 26, N(9), 1287-1290, 1999.

Randriambelo, T., Baray, J. L., and Baldy, S.: The effect of biomass burning, convective venting and transport on tropospheric ozone over the Indian Ocean: Reunion island field observations, J. Geophys. Res, 105(D9), 11813-11832, 2000.

Randriambelo, T., Baray, J. L., Baldy, S., Thompson, A. M., Oltmans, S., and Keckhut, P.: Investigation of the short-time variability of tropical tropospheric ozone, Ann. Geophys., 21(9), 2095-2106, 2003.

Sivakumar, V., Baray, J. L., Baldy, S., and Bencherif, H.: Tropopause characteristics over a southern subtropical site, Reunion Island $\left(21^{\circ} \mathrm{S}, 55^{\circ} \mathrm{E}\right)$ : Using radiosonde-ozonesonde data, J. Geophys. Res., 111, D19111, doi:10.1029/2005JD006430, 2006.

Schumann, U. and Huntrieser, H.: The global lightning-induced nitrogen oxides source, Atmos. Chem. Phys., 7, 3823-3907, 2007, http://www.atmos-chem-phys.net/7/3823/2007/.

Smit, H. G. J., Straeter, W., Johnson, B. J., et al.: Assessment of the performance of ECC-ozonesondes under quasi-flight conditions in the environmental simulation chamber: Insights from the Juelich Ozone Sonde Intercomparison Experiment (JOSIE), J. Geophys. Res., 112, D19306, doi:10.1029/2006JD007308, 2007. 
Stevenson, D. S, Dentener, F. J., Schultz, M. G., Ellingsen, K., van Noije, T. P. C., Wild, O., Zeng, G., Amann, M., Atherton, C. S., Bell, N., Bergmann, D. J., Bey, I., Butler, T., Cofala, J., Collins, W. J., Derwent, R. G., Doherty, R. M., Drevet, J., Eskes, H. J., Fiore, A. M., Gauss, M., Hauglustaine, D. A., Horowitz, L. W., Isaksen, I. S. A., Krol, M. C., Lamarque, J.F., Lawrence, M. G., Montanaro, V., Müller, J.-F., Pitari, G., Prather, M. J., Pyle, J. A., Rast, S., Rodriguez, J. M., Sanderson, M. G., Savage, N. H., Shindell, D. T., Strahan, S. E., Sudo, K., and Szopa, S.: Multimodel ensemble simulations of presentday and near-future tropospheric ozone, J. Geophys. Res., 111, D08301, doi:10.1029/2005JD006338, 2006.

Swap, R. J., Annegarn, H. J., Suttles, J. T., King, M. D., Platnick, S., Privette, J. L., and Scholes, R. J.: Africa burning: A thematic analysis of the Southern African Regional Science Initiative (SAFARI 2000), J. Geophys. Res., 108(D13), 8465, doi:10.1029/2003JD003747, 2003.

Taupin, F. G., Bessafi, M., Baldy, S., and Bremaud, P. J.: Tropospheric ozone above the southwestern Indian Ocean is strongly linked to dynamical conditions prevailing in the tropics, J. Geophys. Res., 104(D7), 8057-8066, 1999.

Taupin, F. G., Beekmann, S., Brémaud, P. J., and Randriambelo, T.: Ozone generation over the Indian Ocean during the South African biomass-burning period: case study of October 1992, Annales Geophysicae, 20, 547-557, 2002.

Thompson, A. M., Witte, J. C., McPeters, R. D., Oltmans, S. J., Schmidlin, F. J., Logan, J. A., Fujiwara, M., Kirchhoff, V. W. J. H., Posny, F., Coetzee, G. J. R., Hoegger, B., Kawakami, S., Ogawa, T., Johnson, B. J., Vömel, H., and Labow, G.: Southern Hemisphere ADditional Ozonesondes (SHADOZ) 19982000 tropical ozone climatology, 1. Comparison with TOMS and ground-based measurements, J. Geophys. Res., 108, 8238, doi:10.129/2001JD000967, 2003.

Thompson, A. M., Witte, J. C., Oltmans, S. J., Schmidlin, F. J., Logan, J. A., Fujiwara, M., Kirchhoff, V. W. J. H., Posny, F., Coetzee, G. J. R., Hoegger, B., Kawakami, S., Ogawa, T., Fortuin, J. P. F., and Kelder, H. M.: Southern Hemisphere ADditional Ozonesondes (SHADOZ) 1998-2000 tropical ozone climatology, 2. Tropospheric Variability and the Zonal Wave-One, J. Geophys. Res., 108, 8241, doi:10.129/2002JD002241, 2003.
Thouret, V., Marenco, A., Logan, J., Nédélec, P., and Grouhel, C.: Comparisons of ozone measurements from the MOZAIC airborne program and the ozone sounding network at eight locations, J. Geophys. Res., 103, 25695-25720, 1998.

Thouret, V., Cammas, J.-P., Sauvage, B., Athier, G., Zbinden, R., Nédélec, P., Simon, P., and Karcher, F.: Tropopause referenced ozone climatology and inter-annual variability (1994-2003) from the MOZAIC programme, Atmos. Chem. Phys., 6, 1033-1051, 2006, http://www.atmos-chem-phys.net/6/1033/2006/.

Tyson, P. D., Garstang, M., and Swap, R.: Large scale recirculation of air over Southern Africa, J. Appl. Meteorol., 35, 2218-2236, 1996.

Tyson, P. D. and Preston-Whyte, R. A.: the weather and Climate of Southern Africa, Oxford Univ. Press, New York, USA, 2000.

Watson, R. T., Albritton, D. L., Barker, T., Bashmakov, I. A., Canziani, O., Christ, R., Cubasch, U., Davidson, O., Gitay, H., Griggs, D., Halsnaes, K., Houghton, J., House, J., Kundzewicz, Z., Lal, M., Leary, N., Magadza, C., McCarthy, J. J., Mitchell, J. F. B., Moreira, J. R., Munasinghe, M., Noble, I., Pachauri, R., Pittock, B., Prather, M., Richels, R. G., Robinson, J. B., Sathaye, J., Schneider, S., Scholes, R., Stocker, T., Sundararaman, N., Swart, R., Taniguchi, T., and Zhou, D.: IPCC, 2001: Climate Change 2001: Synthesis Report, A Contribution of Working Groups I, II, and III to the Third Assessment Report of the Integovernmental Panel on Climate Change, IPCC, Cambridge University Press, Cambridge, UK, and New York, NY, USA, 398 pp., 2001.

Waugh, D. W. and Polvani, L. M.: Climatology of intrusions into the tropical upper troposphere, Geophys. Res. Lett., 27, 38573860, 2000.

Wells, R., Lloyd, S., and Turner, C.: National air pollution source inventory, in: Air pollution and its impacts on the South African highveld, edited by: Held, G., Gore, B. J., Surridge, A. D., Tosen, G. R., Turner, C. R., and Walmsley, R. D., Environmental Scientific Association, Cleveland, USA, 3-9, 1996.

Ziemke, J. R., Joiner, J., Chandra, S., Bhartia, P. K., Vasilkov, A., Haffner, D. P., Yang, K., Schoeberl, M. R., Froidevaux, L., and Levelt, P. F.: Ozone mixing ratios inside tropical deep convective clouds from OMI satellite measurements, Atmos. Chem. Phys., 9, 573-583, 2009, http://www.atmos-chemphys.net/9/573/2009/. 